\author{
Е. А. Галинская \\ Московский государственный университет имени М. В. Ломоносова \\ (Москва, Россия) \\ eagalinsk@mail.ru
}

\title{
ГРАММАТИЧЕСКАЯ ВАРИАТИВНОСТЬ В ЯЗЫКЕ НОВГОРОДСКОЙ ДЕЛОВОЙ ПИСЬМЕННОСТИ КОНЦА ХVІ ВЕКА
}

В статье описываются случаи морфологической и синтаксической вариативности, отраженные в «Записной книге старых и новых крепостей по Новгороду, явленных дьяку Дмитрию Алябьеву» 1597-1598 гг. (РГАДА, ф. 1144, оп. 1, № 1 и №4). При этом рассматриваются только те явления, которые находились за пределами нормы делового языка. «Записная книга» свободно отражает фонетические черты новгородского диалекта конца XVI в., так что написаниям, за которыми усматриваются грамматические особенности, тоже можно доверять. Случаи вариативности таковы. 1. В творительном падеже единственного числа женского рода сосуществовали окончания -ою/-ею и-ој/-еј, хотя при значительном перевесе в сторону -ою/-ею. 2. В местном падеже числительного трие исконная форма трехъ варьировалась с формой, пришедшей из родительного падежа, — треи. 3. Конструкция «два / три / четьре / полтора и др. + форма на -bl/-u» сосуществовала с конструкцией «два / три / четыре / полтора и др. + форма на -a» при явном преобладании первой. 4. Наблюдалась вариативность древнего типа родо-числового синтаксического оформления количественных конструкций (сочетания числительного в именительном / винительном падежах с существительным присоединяли к себе согласуемые слова в форме женского рода) и изредка появляющегося нового типа (согласуемые слова стояли во множественном числе). 5. В дательном и местном падежах женского рода единственного числа притяжательных прилагательных параллельно употреблялись именные и местоименные окончания. 6. В притяжательных конструкциях присутствовала вариативность форм князя, князь, княжсии, княжь, княже и князе. 7. Сосуществовали конструкции с координируемым и некоординируемым причастием при форме именительного падежа существительных. Таким образом, в целом ряде звеньев грамматической системы новгородского диалекта конца XVI в. шли процессы перехода от одного состояния к другому, что и обусловило наличие вариантных форм и конструкций.

Ключевые слова: новгородский диалект конца XVI века, историческая морфология, исторический синтаксис, грамматическая вариативность. 
Исследование А.А. Зализняком новгородских берестяных грамот показывает, что, при всей морфологической специфике древненовгородского диалекта, во многих точках грамматической системы уже в ранний период, когда древненовгородский диалект еще не испытывал влияния говоров центра, существовала некоторая вариативность окончаний.

Например, формы И. и В. пп. мн.ч. твердого варианта $* \bar{a}$-склонения имели окончания $-b$ и $-b l$, хотя и при преобладании окончания $-b$, например: a) к‘s $\mathbf{b}$ № 247

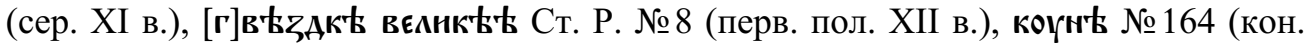
XI - перв. четв. XII в.), подъшьв № 438 (кон. XII - нач. ХІІІ в.); б) коүплєны №439 (кон. XII — нач. XIII в.), роүкы №9 (сер. XII в.).

Есть отдельные указания на то, что в И. и В. пп. дв.ч. мягкого варианта *ā-

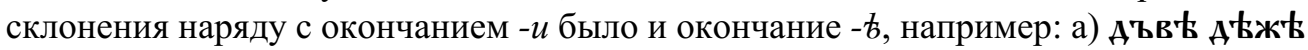
(мера количества зерна) № 863 (втор. четв. ХІІ в.), б) · $\overrightarrow{\mathbf{B}} \cdot$ грнвнн $<\ldots>$ моє (с графическим эффектом $b \rightarrow e$ ) №483 (втор. пол. ХІІІ в.).

Такая же вариативность наблюдалась в форме И.п. мн.ч. муж. р. *о̆-склонения например: а) въкоүпннк' № 821 (сер. XII в.); б) смьрьдн № 247 (XI в.) и в форме М.п. ед.ч. муж. р. мягкого варианта * о̆-склонения, например: а) на кон' № 78 (вт. пол. ХІІ в.); б) на т[њ]Хонн конн №926 (перв. пол. ХІІІ в.) [Зализняк 2004: 98-99, 108-109].

Вариативность в ненормированном диалектном языке вообще встречается не так уж редко, в чем мы можем убедиться, обратившись к современным русским говорам. Так, в пределах южнорусского наречия и среднерусских говоров есть целый ряд ареалов, где сосуществуют формы с окончаниями - $a$ и -bl в И.п. мн.ч. существительных среднего рода с основой на парный твердый согласный типа сёльl, о́кны, вёдры и сёла, о́кна, вёдра [ДАРЯ II, карта 33], а на востоке великорусской территории (и на севере, и на юге) имеются говоры, где сосуществуют формы типа в го́роде и в городу́ [ДАРЯ II, карта 22].

При работе с деловыми текстами XVI-XVII вв. следует обращать внимание на явления, находившиеся за пределами нормы делового языка, в которую входи-

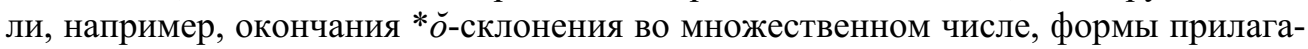
тельных Р.п. ед.ч. жен. р. на -ые. Тогда, выявив вариативность, можно проследить процесс видоизменения и становления тех или иных элементов грамматической системы.

Материалом для настоящего исследования послужили две рукописи новгородского происхождения, хранящиеся в РГАДА (ф. 1144 «Новгородская приказная палата», оп. 1, № 1 и №4). Название книги № 1 в описи архива - «Книга записная кабалам на холопей», а название книги №4 там же - «Книга кабальная записей на разных лиц». На сайте РГАДА обе они имеют одинаковое название «Записная книга старых и новых крепостей по Новгороду, явленных дьяку Дмитрию Алябьеву» 1597-1598 гг., но по сути представляют собой один документ, учтенный в РГАДА в виде двух самостоятельно существующих единиц хранения, которые были оформлены по раздельным переплетам еще в конце XIX в., когда они пребывали в Московском архиве Министерства юстиции. Записные книги старых 
и новых крепостей велись в Новгороде с 1 декабря 1597 г. по 31 января 1598 г. Они представляют собой изложение полных, докладных и кабальных грамот, оформлявших права на владение холопами в XVI в. (в основном в последней его четверти) и в некоторых весьма редких случаях в начале XVI в. и последней трети XV в. Важно заметить, что мы имеем дело в основном с пересказами указанных документов, а не со списками с них, хотя небольшие фрагменты списков иногда присутствуют. Дело в том, что обычно пересказы, в отличие от списков, которые копируют более ранние оригиналы, отражают языковую ситуацию периода, когда они создаются (ср. анализ типов падежного синкретизма, отраженного списками и пересказами XVII в. псковских грамот XIV-XV вв. [Алпатова 2005: 89-92]). Книга №4 состоит из 230 лл., на каждом из которых стоит скрепа дьяка Дмитрия Алябьева, служившего в Великом Новгороде с марта 1594 г. по май 1602 г., см. [Веселовский 1975: 21]. Книга № 1, состоящая из 201 лл., имеет скрепу Дмитрия Алябьева на лл. 1-141, которые и были изучены для настоящего исследования. Далее приплетена челобитная грамота 1596 г. (л. 142); оставшиеся листы написаны в XVII в., поскольку лл. 143-167 скреплены подписью дьяка Федора Опраксина (Апраксина), служившего в Великом Новгороде с 21 марта 1624 г. по 1625/26 г. [Там же: 28], а лл. 168-201 имеют скрепу Ивана Зиновьева, о котором известно, что он был дьяком в Великом Новгороде в 1660 г. [Там же: 195].

Лл. 1-141 книги № 1 (далее - К1) написаны шестью почерками:

1-й почерк: лл. 1-8 об.; 2-й почерк: лл. 9-75 об.; 3-й почерк: лл. 76-77, часть л. 85 об., сер. л. 90 об. — 92 об.; 4-й почерк: лл. 77 об. — 90 об. до сер. л., 93-93 об.; 5-й почерк: лл. 94-125 об.; 6-й почерк: 126-141 об.

Книга № 4 (далее - К4) написана пятью почерками:

1-й почерк: лл. 1-32 об.; 2-й почерк: лл. 33-104 об.; 3-й почерк: лл. 105-136 об.; 4-й почерк: лл. 137-222 об.; 5-й почерк: лл. 223-230 об.

Следует заметить, что 1-й и 3-й почерки К4 внешне схожи, графически относятся к одному типу, но анализ орфографических особенностей показывает, что они принадлежат разным писцам. Так, в 1-м почерке 35 замен $\mathbf{b}$ на е в слоге под ударением и 18 случаев замены в этой же позиции в на и, а в 3-м буква в употребляется в основном в соответствии с этимологией, так что отмечены только три замены b на е и три замены ъ на и в ударном слоге при примерно равном количестве листов, занятых каждым из почерков. Показательны также окончания И.-В. пп. мн.ч. прилагательных (в том числе субстантивированных): в 1-м почерке сосуществуют примерно в равном количестве формы с окончаниями -ые (например, двъ служилье кабаль К4-12) и -ыл (например, две служилья кабаль К4-10 об.), а в 3-м почерке есть только окончание -ьле (например, три служильле кабаль К4-110) ${ }^{1}$.

${ }^{1}$ При приведении примеров из рукописей используется упрощенная орфография: i передается как и, w как о, $\mathbf{s}$ как з, га и $\mathbf{A}$ как я, そ2 как кс, юr как ф; титла раскрываются, а восстановленные буквы берутся в круглые скобки. Во всех почерках в большинстве случаев употребления букв b и $\mathbf{b}$ они имеют единый размашистый начерк. В тех случаях, когда твердость или мягкость согласного очевидна, ставятся соответственно буквы $\mathbf{b}$ и $\mathbf{b}$, а там, где твердость или мягкость могут быть связаны с диалектными особенностями, используется нейтральный знак $\mathbf{b}$. 
При этом 3-й почерк К1 и 5-й почерк К4 принадлежат руке одного и того же писца. Это видно как из анализа начерков, так и из графико-орфографических навыков, представленных в обоих почерках. 3-м почерком К1 написаны пять листов, а 5-м почерком К4 - восемь листов, и в обоих почерках одинаково активно заменяется в на и в слоге под ударением при отсутствии замен и на $\mathbf{b}$; используется лигатура «ва», где к «в», пишущемуся в виде треугольника, снизу без отрыва руки приписывается «а» в виде греческой альфы (помимо этого, в 3-м почерке К1 есть аналогично устроенная лигатура «на», а в 5-м почерке К4 - «ца»).

Одному и тому же писцу принадлежат 4-й почерк К1 и 4-й почерк К4. Об этом можно сделать вывод не только по графическому типу письма, но и в результате анализа орфографии и языка обоих отрезков текста. И в том и в другом почерке имеются многочисленные замены в на и, которым сопутствуют обратные замены и на ъ. И там и там мы находим отсутствующее в других почерках обозначение долгого глухого шипящего буквосочетаниями сщ, сш: пусщи К К1-79 об., прикасшуики К1-79 об., восшаная К1-89; Вересщуаги (Р. ед., имя) К4-138 об., 172, восщаная К4-142, исщеюю ('истца') К4-195, 203, Насщзоки К $4-198$, с плосщуа ${ }^{\text {ди }}$ К4-172, отвесшика (В.п.) К4-195. И, наконец, в этих двух почерках мы находим форму М.п. (и в одном случае Р.п.) слова оба с окончанием -yx: в обию кабала ${ }^{\mathrm{x}}$ К1-86 об., в ои $\mid$ бю ${ }^{\mathrm{x}}$ кабала ${ }^{\mathrm{x}}$ (с опиской) К1-83 об., в обию ${ }^{\mathrm{x}}$ кабала ${ }^{\mathrm{x}} \mathrm{K} 4-183,192$, у полнь ${ }^{\mathrm{x}}<\ldots>$ ув обию ${ }^{\mathrm{x}}$ 4-212об.

Итак, обе книги насчитывают девять почерков. Без сомнения, все писцы были новгородцами, так как они отражают фонетические диалектные черты, которые реконструируются по другим деловым текстам новгородского происхождения конца XVI - первой половины XVII в. (см., например, [Галинская 2002: 12-42]). Самая яркая из этих черт - взаимная мена букв њ и и в ударных, а иногда и в безударных слогах. Впрочем, интенсивность замены в на и у разных писцов разная - у некоторых примеры обнаруживаются в обильном количестве, а у других - редко. Обратная (гиперкорректная) замена и на $\mathbf{b}$ есть не во всех почерках. Ср. некоторые примеры:

\begin{tabular}{|c|c|c|}
\hline & Замена $b$ на $u$ & Замена $u$ на $b$ \\
\hline $\begin{array}{l}\text { K1, 1-й по- } \\
\text { черк }\end{array}$ & 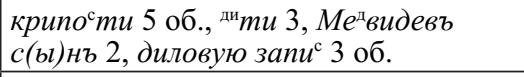 & 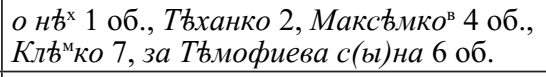 \\
\hline $\begin{array}{l}\text { K1, 2-й по- } \\
\text { черк }\end{array}$ & дви 22 об, згорила 43 об. & онъ 27 об., 28, 31, 42 об., 52 об. \\
\hline $\begin{array}{l}\mathbf{K 1}, 3-\text { й по- } \\
\text { черк = К2, 5-й } \\
\text { почерк }\end{array}$ & 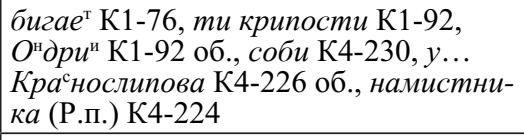 & \\
\hline $\begin{array}{l}\mathbf{K 1}, 4-и ̆ \text { по- } \\
\text { черк = K2, 4-й } \\
\text { почерк }\end{array}$ & $\begin{array}{l}\text { сестри (Д.п.) К1-90, Тимофию К1-82, } \\
\text { влади К К4-191 об., соби К4-212 }\end{array}$ & 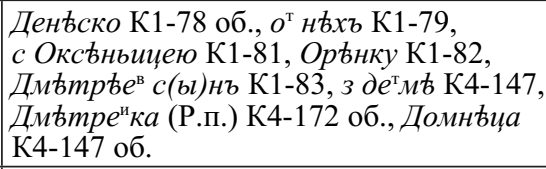 \\
\hline $\begin{array}{l}\text { K1, 5-й по- } \\
\text { черк }\end{array}$ & $\begin{array}{l}\text { дивку } 95 \text { об., с... нимкою 99, у дида } \\
114 \text { об., велил } 110 \text { об., на их дитеи } \\
101 \text { об. }\end{array}$ & 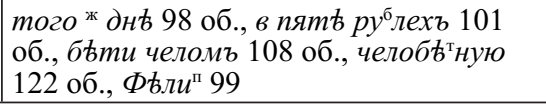 \\
\hline
\end{tabular}


Грамматическая вариативность в языке новгородской деловой письменности конца XVI века

\begin{tabular}{|c|c|c|}
\hline $\begin{array}{l}\text { K1, 6-й по- } \\
\text { черк }\end{array}$ & 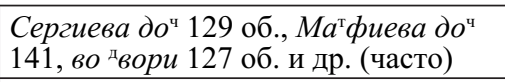 & 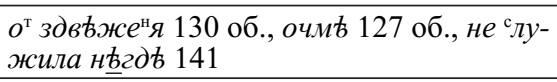 \\
\hline $\begin{array}{l}\text { K4, 1-й по- } \\
\text { черк }\end{array}$ & $\begin{array}{l}\text { вели } 1 \text { об., не умие } 3, \text { дити } 10 \text { об., } \\
\text { Фадинкова (Р.п.) } 23\end{array}$ & \\
\hline $\begin{array}{l}\text { K4, 2-й по- } \\
\text { черк }\end{array}$ & а ничто... б(о)гъ пошле 57 & за Оксъньею 46, Фетьньица 70 об. \\
\hline $\begin{array}{l}\text { K4, 3-й по- } \\
\text { черк }\end{array}$ & $\begin{array}{l}\text { Сергиеву до } 13 \text { об., Патракиеву до } \\
128\end{array}$ & $\begin{array}{l}\text { онь } 118, \text { Фетьика } 125, \text { перед ... } \\
\text { Черкаскъ }{ }^{\mathrm{m}} 117 \mathrm{oб.}\end{array}$ \\
\hline
\end{tabular}

В К1 и К4 свободно отражаются и другие фонетические явления, так что написаниям, за которыми мы усматриваем грамматические особенности новгородского диалекта конца XVI в. и которые находятся за пределами норм делового языка, тоже можно доверять. Перейдем, таким образом, к некоторым разновидностям грамматической вариативности, отраженным в исследованной рукописи.

1. В истории русского языка прошел процесс отпадения конечных безударных гласных фонетического слова. А. А. Зализняк сформулировал правило (с небольшим количеством исключений), которому подчинялся этот процесс: отпадавшему гласному предшествовал одиночный согласный или группа [ст], и такие гласные не составляли отдельного морфа. В ряде случаев процесс носил факультативный характер (подробнее см. [Зализняк 2002: 550-558]). Под действие указанного правила попадала и флексия творительного падежа слов женского рода -ою/-ею. В силу специфики содержания записной книги в ней употребляется огромное количество форм творительного падежа, ср.: ... да Нилова жена з де $e^{\mathrm{T}} м и$ с Лешкою да с Миккою да с Васкою да с Богда $a^{\mathrm{H}} \kappa o^{\mathrm{M}} \partial а$ з Гру

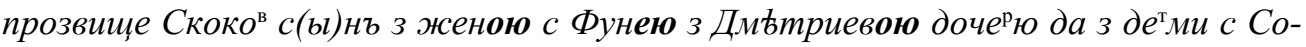
зо ком прозвище с Пер вушкюю да с Матюшею да с О ${ }^{\Phi}$ роскою да с Нени кою К4-191. При этом подавляющее большинство таких форм имеют окончание с не отпавшим еще гласным, тогда как формы с окончанием -ои/-еи (например, с муже c $^{\text {Tuмоu- }}$ кои К1-81 об., за дочер ю своею за Федо сеи К1-100 об., с Васии ско и с Фомино чер на их фоне крайне малочисленны. Причем есть почерки, в которых вообще всегда употребляются только окончание -ою/-ею - К4, 1-й почерк и К4, 3-й почерк. Таким образом, вариативность окончания творительного падежа женского рода, хотя и существовала, но в конце XVI в. очень большой перевес был в сторону флексии -ою/-ею, что и не удивительно, поскольку даже в XIX в. формы с этой флексией были вполне употребительны, ср. у Пушкина в «Капитанской дочке»: Матушка отыскала мой паспорт, хранившийся в ее шкатулке вместе с сорочкою, в которой меня крестили, и вручила его батюшке дрожащею рукою.

2. В древнерусском языке слово трие имело, как известно, парадигму множественного числа * $\iota$-склонения, то есть после прояснения редуцированных формы выглядели так: И.п. трие/три, Р.п. треи (-еј), Д.п. трем, В.п. три, Т. п. треми, М.п. трех.

Одна из первых инноваций, произошедших в склонении слова трие, — это влияние местного падежа на родительный и появление в нем формы трех. О.Ф. Жолобов обнаруживает форму трехъ в памятниках XIV в. [Жолобов 2006: 243]. 
Однако во 2-м почерке К1 отмечается результат весьма нестандартного пути развития противоположного типа: здесь в М.П. регулярно употребляется форма треи: кабала... в треи рубле К1-23, 24, 35, 44 об., кабала... в тре $e^{\mathrm{x}}$ рублех К1-38 об., 50, 54 об. Тут произошла нетривиальная экспансия формы Р.п. на М.п. Насколько мне известно, ранее такая форма М.п. в памятниках русской письменности не отмечалась. Но случаи употребления формы трехъ в этом почерке тоже есть: в тре рубле К К1-12, 18, 47 об., 49, 56 (2 р.). Для остальных почерков форма трехъ единственная. Склонение числительных не входило в зону нормирования делового языка, поэтому можно думать, что обе формы существовали в новгородском диалекте в широком смысле этого понятия, а варьирование могло быть как между разными говорами новгородского типа, так и в пределах одного говора.

3. В процессе преобразования числительных, который был весьма сложным, происходило и изменение их синтаксической сочетаемости. В частности, в результате утраты категории двойственного числа бывшая форма И.-В. пП. дв. ч. суще-

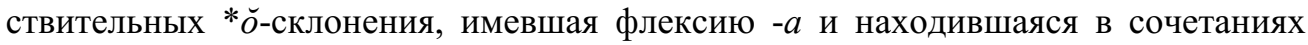
со словами два, оба, стала осознаваться как форма Р.п. ед.ч. Вновь сформировавшаяся сочетаемость распространилась и на два других счетных слова - трие, чеmыре, которые исконно согласовывались с существительными, стоявшими в И.-В. пп. (И. трие/четыре столи, В. три/четыри столь), отчего сейчас в русском литературном языке представлены сочетания не только типа два дуба, но и типа три дуба, четыре дуба. О.Ф. Жолобов пишет, что они утвердились лишь в XVII в., «получив распространение во второй половине XVI в.» [Жолобов 2006: 226], хотя спорадически формы на - $а$ проникали в сочетание с числительным три и раньше (приводятся три примера из новгородских берестяных грамот XIV в. и четыре примера из книжных текстов XIV-XV вв.) [Там же: 225-226].

В исследуемой новгородской рукописи конца XVI в. перед нами предстает следующая картина.

С числительными три и четыре в основном сохраняется старая сочетаемость (в тексте представлены формы В.п.): три рубли К1-5 об., 76, 133, 134, три рубли К1-45, К4-87 об., 139, 140, 141, 146 об., 179 об. и др., три рубли К4-85, 85 об., 86, три сыны К4-22, четыре руб ли К1-8, 46 об., об., 129, 132, 133 об., 137, К4-38 об.,

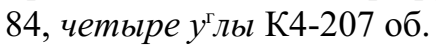

Но изредка встречаются и новые формы: три руб $л я$ К1-114, К4-118, четыре ру${ }^{\circ}$ ля К2-225.

При этом исконные формы на - $а$ при слове два единичны: за два рубля К1-33, два рубля К1-76 об., К4-124 об. Видимо, в новгородском диалекте влияние старой сочетаемости существительных с два было не столь сильно, хотя, несомненно, имело место. Более продуктивным оказалось противоположное влияние - конструкция типа три рубли воздействовала на сочетание существительного с числительным два, отчего многочисленными оказались следующие примеры: два рубли К1-10, 20 об., 64, 138 об., два рубли К1-77 об., 80 об., 123, 141, К4-22, 61 об., 137 об., 138, 139 об., 141 об., 142, 146, 160 об., 176, 197, 199 об. и др. Мало того, существительные на -bl/-u могли вытеснять существительные на - $a$ из «половинного» счета, 
где исконной была форма Р.п. существительного (полъ вътора руглг), отчего мы находим: полтора // рубли К4-153 об., 200 об.//201, полтора рубли К4-139, 224,

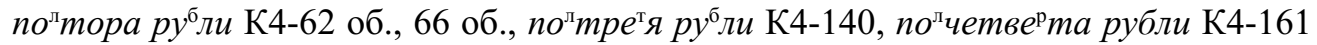
об., хотя бывает и полтора рубля К4-128 об., погтре я рубля К4-119.

В итоге сформировалась вариативность: конструкция «два / три / четыре / полтора и др. + форма на -bl/-u» сосуществовала с конструкцией «два / три / четыре / полтора и др. + форма на - $a \gg$ при значительном преобладании первой. Бо́льшая или меньшая архаичность сочетания числительного с существительным здесь роли не играла: например, в 5-м почерке К4 сочетаются два руб ли 230 и четыре рубля 225. Впрочем, возможно, были индивидуальные предпочтения в выборе одной из двух конструкций. Так, писец, которому принадлежит 4-й почерк К1 и 4-й почерк К4, использует только конструкцию «два / mpu / четыре + форма на -bl/-u».

4. Как известно, под влиянием того, что слова пять - девять были сущест-

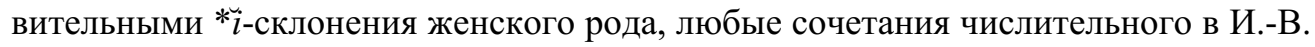
пп. с существительным присоединяли к себе согласуемые слова в форме женского рода [Зализняк 2004: 168]. Такое согласование представлено и в текстах записной книги (встречены только формы В.п., примеры для сокращения списка приводятся без учета срединных выносных букв): два рубля московскую К1-76 об., за два рубля московскую К1-33, два рубли московскую К1-64, 80 об., 123, 138 об., три рубли московскую К1-5 об., 76, 85, об., 86, 133, 134 об., три рубля ноугородикую К1-114, три рубли ноугородикую К4-87 об., четыре рубли московскую К1-8, 46 об., 129, 132, 133 об., 137, четыре рубли денег ноугородикую К4-84, пят рубле $е^{\mathrm{B}}$ московскую К1-127 об., 128 об., 130 об., 135 об., 137, 138, 139 об., шесть рублев московскую К1-45 об., 47, шесть рубле денег московскую К1-46, семъ рубле рублев московскую К4-6, полтора рубли ноугородикую К4-62 об.

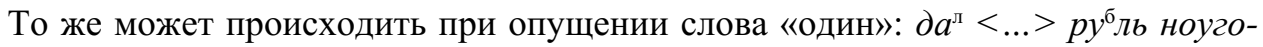
родикую К1-2 об. Однако чаще в таком случае представлено согласование в муж-

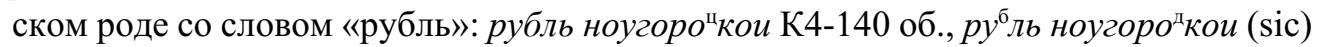
К4-198 об., руб ль ноугоро ияки К1-104, рубль наогоро ичко ${ }^{\text {п }}$ (sic!) К4-21 об., взял $<\ldots>p y^{6} л ь$ моско ${ }^{\mathrm{B}}$ скои К1-124. Сочетания со словами, обозначающими другие числа, также могут присоединять к себе определения не в женском роде, причем есть два варианта форм множественного числа - более частотный В.п. и более редкий Р.п.: 1) два рубли ноугоро кие К4-142, погтора рубля ноугоро иякие К1-128 об., четьлре рубли ноугоро иякие К4-38 об., погтора руб ли ноугоро иякие К4-66 об., три ру ли

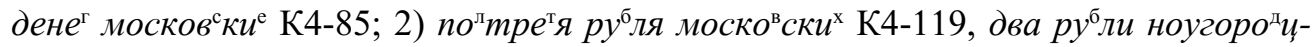
кихъ К4-61 об.

Таким образом, в конце XVI в. сосуществовали древний вариант родо-числового синтаксического оформления количественных сочетаний и новый вариант при преобладании первого.

5. В праславянском языке притяжательные прилагательные склонялись по именному склонению, а в древнерусском языке в их парадигмы начали постепенно проникать местоименные формы. Первыми приобрели полные формы Т. п. ед. ч. муж. и ср. р. и косвенные падежи множественного числа, например, со розбонннковымъ 
товаромъ Гр. рижан к Витебскому кн. Михаилу Константиновичу ок. 1300 г., ровьнХ'ъ вЊ(вернць) 'денег за рабыню' Новг. бер. гр. №335 (60-70-е гг. ХІІ в.),

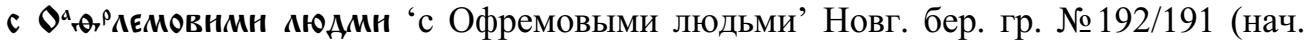
XIV в.). Материалы памятников письменности показывают, что становление местоименных форм у притяжательных прилагательных во множественном числе завершилось в XIII в., а в Т.п. ед. ч. муж. и ср. р. — к началу XIV в. [Кузнецов, Иорданиди, Крысько 2006: 166, 173]. Постепенно новые местоименные формы стали проникать и в другие косвенные падежи единственного числа (сейчас их нет только у притяжательных прилагательных с суффиксом -ов в Р. и Д. пп. ед. ч. муж. и ср. р.).

Далее будет приведен материал записной книги, который позволяет показать, как в конце XVI в. складывается картина в тех косвенных падежах мужского и женского рода (средний род не представлен), которые сохранили именные флексии после XIV в., т. е. в Р., Д. и М. пп. муж. и жен. p. ${ }^{2}$

В мужском роде есть только именные флексии: Р.п. де ги заняла ув $a^{\mathrm{x}}$ мета дмитриева с(ь)на жолтухина К1-23, с намьстнъча докладу К4-195 об. Д.п. михаилу ста ${ }^{p}$ кову с(ь)ну К1-29 об., по федорову велен ю К4-107. М.п. в ч(е)л(о)в(в)ки

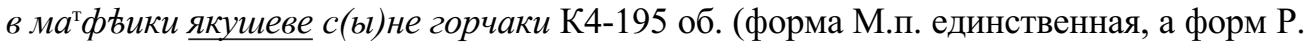
и Д. пп. много, но они интереса не представляют, поэтому приведено только по два примера).

В женском роде картина не столь однозначна.

В Р.п. имеются лишь именные флексии -bl и -b/-e (вариативность -bl/-b обусловлена двумя типами падежного синкретизма в именном склонении новгородского диалекта XVI в., см. [Галинская 1991: 32]; вариативность ъ/е орфографическая):

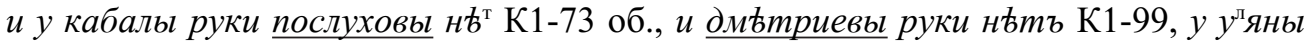
михаиловы жены трусова К4-35 об., 36, да степановы дочерь (\$ исправлен из и)

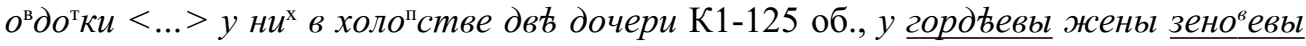
дочери К4-38 об., в ма ри ино ивановы жены <..> мьсто К4-59 об., в сестры своеи оленино мьсто яковлевь жены кобылина К4-171, у ма и у ивановъ дочери новокщенова К1-100 об., з боркове улицьь К1-132 об., 133.

В Д.п. и М.п. обнаруживается сосуществование именных и местоименных окончаний.

В Д.п. именное окончание -b(e) и местоименное окончание -ои представлены примерно в равных небольших количествах: сестре своеи ану'

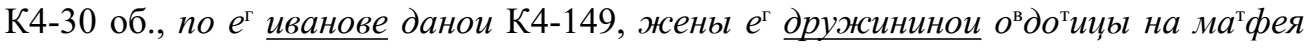
и на ег жену на мала"ю дъла не дълати никакова 'Дружининой жене Овдотьице не следует предъявлять претензии к Матфею и его жене Маланье’ К1-62. В то же время в М.п. именные окончания -b(e) и -bl встречаются регулярно в больших количествах (например: жена ${ }^{\mathrm{T}}<\ldots>$ на дени еве дочери $\mathrm{K} 4-110$, жена ${ }^{\mathrm{T}}<\ldots>$ на неждане на мишуковь дочери К4-123), а местоименное окончание -ои отмечено толь-

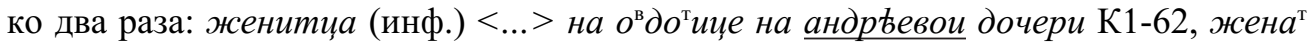

2 Т. п. ед.ч. жен. р. не рассматривается, поскольку там именные и местоименные формы всех прилагательных исконно совпадали (например, новою). 


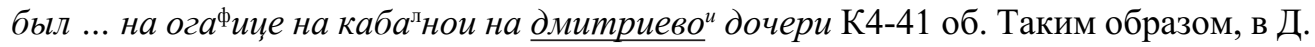
и М. пп. присутствовала вариативность именных и местоименных флексий, и можно констатировать, что в М.п. местоименная флексия еще не была частотной.

6. Из посессивных конструкций в древнерусском и старорусском языке наиболее частотными были две: с двумя притяжательными прилагательными типа княжь Федоровъ намьстьникъ ('наместник князя Федора') и с родительным принадлежности и притяжательным прилагательным типа Ивановъ крестьянинъ Климова ('крестьянин Ивана Климова'). Обе эти конструкции, часто в еще более осложненном виде, например с относительным прилагательным, образованным от имени, широко представлены в «Записной книге». Значительная вариативность здесь наблюдается при упоминании принадлежности князю, называемому по имени или по имени и фамилии.

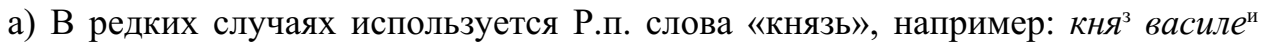

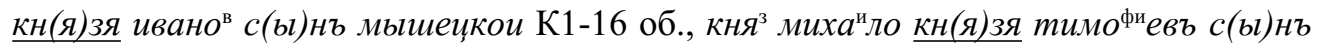
мызие $^{\mathrm{T}}$ изо ${ }^{\mathrm{n}} \mathrm{K} 1-92$.

б) Столь же редко встречается несклоняемая форма князь: $\kappa н(я)_{3}$ ив $a^{\mathrm{H}} \underline{\kappa \mu(я))_{3 b}}$

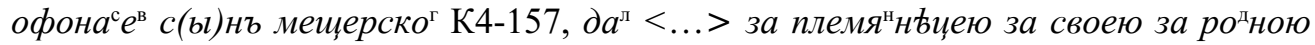
за тан яною за кня Можно полагать, что эта форма была усеченной и застывшей, такое известно в современной разговорной речи с именами при отчествах: у Михал Иваньча, к Василь Петровичу и т. д. Доказательством того, что так и было, служат случаи, где форма князь написана вместо Р.п. князя вне притяжательных конструкций: $o^{\mathrm{T}}$ великого кн(я)зь ивана василевичя К4-11, кн(я) $)^{3}$ ивана де ге дошли К4-124, за пе-

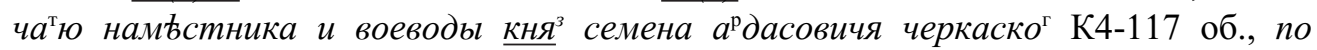
г(о)с(у)дар (е)ве из(а)ря и великого кн(я)з ивана василевичя всеа русии грамоте К4117 об., $o^{\mathrm{T}} \underline{\kappa \mu(я)^{3}}$ миха ${ }^{\mathrm{n}} л а$ федорови ${ }^{\text {ча }} \mathrm{K} 4-118, o^{\mathrm{T}} \underline{\kappa н(я)^{3}}$ семена романовичя К 4-119.

в) Один раз отмечено притяжательное прилагательное «княжии»: писано та ${ }^{\mathrm{M}} г$

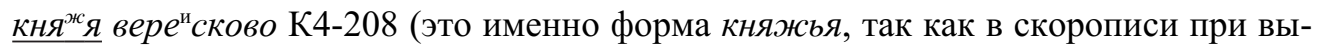
несении над строкой буквы согласного перед буквой гласного опускается обозначение йота).

г) Частотно употребление притяжательного прилагательного «княжь» ${ }^{3}$, например:

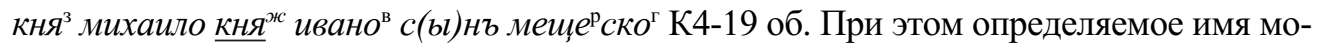
жет быть не мужского рода и стоять не только в И.п., но и в косвенных падежах, ср.:

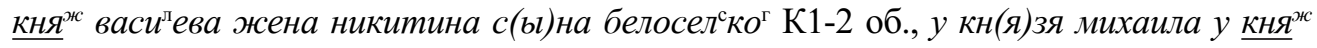
тимофъева с(ь)на мышецког К1-16 об., кня жимофиеву с(bl)ну К1- 82 об. Таким образом, форма княжь не в И.п. ед.ч. муж.р. также была усеченной и застывшей.

д) Столь же часто употребляется еще одна застывшая форма - княже, причем определяемое имя также может быть мужского или женского рода и стоять в лю-

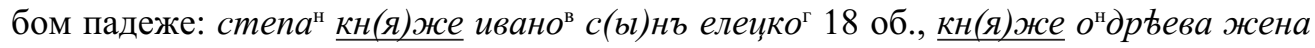

${ }^{3}$ Возможно, что это прилагательное, образованное по праславянской модели с суффиксом *j, было еще живым, поскольку есть и другие аналогичные случаи: митрополич $\partial u{ }^{\mathrm{k}} \mathrm{K} 4-123$, митро-

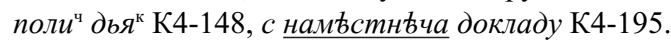


К4-187, де ги заняли у кн(я)же дмитрие скоо княини кропо кина К1-17, кн(я)зю ивану кн(я)же иванову с(ь)ну елецког К1-45.

е) И, наконец, видимо, в результате контаминации между Р.п. князя и притяжательным княже появляется застывшая форма князе: кн(я)зь егуб да кн(я)зь рома

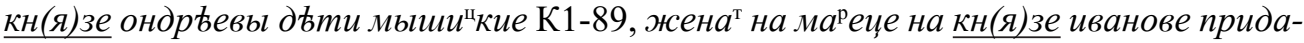

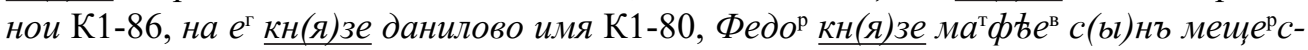
кого К4-148.

Итак, в притяжательных конструкциях наблюдается вариативность форм князя, князь, княжии, княжь, княже и князе, причем они могут варьироваться в одной

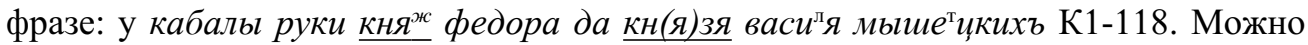
предположить, что в последних двух случаях княже и князе становились своего рода первыми частями сложных слов с соединительным гласным.

7. В современных севернорусских и западных среднерусских говорах распространены конструкции «И.п. имени + некоординируемая форма краткого страдательного причастия» типа курочка унесено, см. [Кузьмина, Немченко 1971: 29-36 и карта № 1]. В записной книге встречены такие конструкции наряду с конструкциями с координируемым причастием. Приведем некоторые примеры.

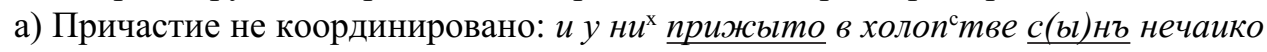
да до м матрушка К1-53, на кабаль подписано рука губново стрость К4-169, на заде данои написано рука ждана тьр ${ }^{\mathrm{p}}$ кова К1-39//39 об., на печати рвзано пр(е)ч(и)стая

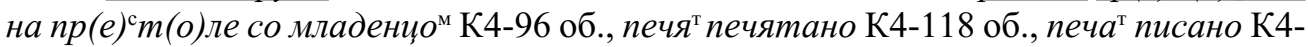
147, печа че черено К4-207 об., печати писано 230 об.

б) Причастие координировано: кабала писана К1-115 об., печа ${ }^{\mathrm{T}}$ писана К4-22,

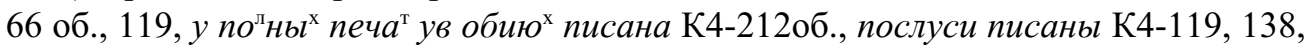
прикашики < .. > писаны К4-122 об., ... которые писаны К4-47 об.

При этом бывает, что две разнотипные конструкции стоят рядом: писано та $2 a$ кня я вере сково да туто ж писана птица К К4-208.

Интересно заметить, что если в конструкцию вклинивается деепричастие, то

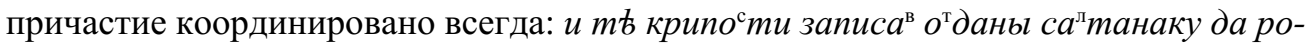

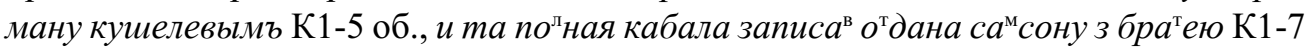
об.//8, и та даная и кабала записа ${ }^{\mathrm{T}}$ дана богдану зеленину К4-223 (подобные случаи весьма многочисленны).

Таким образом, мы видим, во-первых, что конструкции с некоординируемым причастием, характерные сейчас для новгородских говоров, были достаточно распространены уже в XVI в. (в новгородских берестяных грамотах отмечены лишь

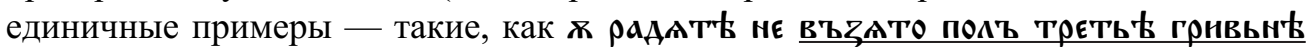

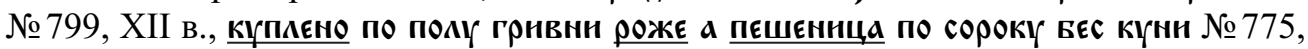
XIII в.), а во-вторых, что они еще сосуществовали с конструкциями, в которых причастие координировано.

Итак, в целом ряде звеньев грамматической системы новгородского диалекта конца XVI в. шли процессы перехода от одного состояния к другому, что и обусловило наличие вариантных форм и конструкций. 


\title{
Источники
}

ДАРЯ II - Диалектологический атлас русского языка (Центр европейской части СССР). Вып. ІІ. Морфология. М., 1989.

\section{Литература}

Алпатова E. А. Формы родительного-дательного-местного падежей единственного числа существительных с исторической основой на *- $a$ в памятниках псковской письменности XIV-XVII веков. Дис. ... канд. филол. наук. М., 2005.

Веселовский С. Б. Дьяки и подьячие XVI-XVII вв. М., 1975.

Галинская E.A. К истории синкретичных именных форм в русских северо-западных говорах // Вестник Московского университета. Серия 9. Филология. 1991. № 5. C. 28-36.

Галинская Е. А. Историческая фонетика русских диалектов в лингвогеографическом аспекте. М., 2002.

Жолобов О. Ф. Числительные / Историческая грамматика древнерусского языка. T. IV. М., 2006.

Зализняк А. А. Правило отпадения конечных гласных в русском языке // Зализняк А.А. «Русское именное словоизменение» с приложением избранных работ по современному русскому языку и общему языкознанию. М., 2002. С. 550-558.

Зализняк А. А. Древненовгородский диалект. М., 2004.

Кузнецов А.М., Иорданиди С. И., Крысько В.Б. Прилагательные / Историческая грамматика древнерусского языка. Т. III. М., 2006.

Кузьмина И. Б., Немченко Е.В. Синтаксис причастных форм в русских говорах. M., 1971.

\author{
Elena A. Galinskaya \\ Moscow State Lomonosov University \\ (Moscow, Russia) \\ eagalinsk@mail.ru
}

\section{GRAMMATICAL VARIATION IN THE LANGUAGE OF LATE 16TH CENTURY NOVGOROD BUSINESS WRITING}

The article describes cases of morphological and syntactic variability as reflected in the Book of Old and New Serfdoms in Novgorod Presented to the Clerk Dmitry Alyabyev of 1597-1598 (RGADA, Fund 1144, Register 1, No. 1 and 4). It should be noted that only those phenomena which were outside the norms of the business language are considered. The Book of Old and New Serfdoms» effortlessly reflects the phonetic features of the Novgorod dialect of the late $16^{\text {th }}$ century; spellings reliably reflect grammatical features. The cases of variation are as follows: 
1. In the Instr. Sg. Fem., the endings -oju/-eju and -oj / -ej coexisted, albeit with considerable dominance of -oju/-eju.

2. In the Loc. of the numeral triye, the original form trekh varied with an unusual form trey which came from Gen.

3. The construction "two / three / four / one and a half, etc. + form on $-y /-i$ " coexisted with the construction "two / three / four / one and a half, etc. + form on - $a$ " with predominance of the former.

4. Variability of the ancient type of quantitative constructions (numeral in Nom. / Acc. and the noun + coordinated words in the feminine form) and sporadic use of a new type (words coordinated in the plural) were observed.

5. Nominal and pronoun inflexions in the Dat. and Loc. Fem. of possessive adjectives coexisted.

6. In the possessive constructions there was variability amongst the forms knyazya, knyaz', knyazhii, knyazh', knyazhe, knyaze.

7. Uncoordinated forms of short participles coexisted with coordinated forms.

This variance of forms and structures was caused by processes of transition between states in the grammatical system of the Novgorod dialect of the late $16^{\text {th }}$ century.

Keywords: Novgorod dialect of the late $16^{\text {th }}$ century, historical morphology of Russian, historical syntax of Russian, grammatical variation.

\section{References}

Alpatova E.A. Formy roditel'nogo-datel'nogo-mestnogo padezhey yedinstvennogo chisla sushchestvitel'nykh $s$ istoricheskoy osnovoy na *av pamyatnikakh pskovskoy pis'mennosti XIV-XVII vekov. Thesis (Moscow State Lomonosov University). Moscow, 2005.

Galinskaya E. A. K istorii sinkretichnykh imennykh form v russkikh severo-zapadnykh govorakh. Vestnik Moskovskogo universiteta. Seriya 9. Filologiya. 1991. №5. S. 28-36.

Galinskaya E. A. Istoricheskaya fonetika russkikh dialektov v lingvogeograficheskom aspekte. Moscow, 2002.

Kuz'mina I.B., Nemchenko E.V. Sintaksis prichastnykh form v russkikh govorakh. Moscow, 1971.

Kuznetsov A. M., Iordanidi S. I., Krys'ko V. B. Prilagatel'nyye (Istoricheskaya grammatika drevnerusskogo yazyka. Vol. III). Moscow, 2006.

Veselovskiy S. B. D'yaki i pod'yachiye XVI-XVII vv. Moscow, 1975.

Zaliznyak A. A. Pravilo otpadeniya konechnykh glasnykh v russkom yazyke. In: Zaliznyak A.A. «Russkoye imennoye slovoizmeneniye» s prilozheniyem izbrannykh rabot po sovremennomu russkomu yazyku i obshchemu yazykoznaniyu. Moscow, 2002. P. 550558.

Zaliznyak A. A. Drevnenovgorodskiy dialekt. Moscow, 2004.

Zholobov O.F. Chislitel'nyye (Istoricheskaya grammatika drevnerusskogo yazyka. Vol. IV). Moscow, 2006. 